\title{
Bi-lingual Newspaper as an Expression of a Fake Multicultural Educational Policy in Israel
}

\author{
Lea Baratz \\ Department of Literature, Achva-College of Education, Israel \\ Tel: 972-3969-1922Ｅ-mail: lbaratz@netvision.net.il \\ Roni Reingold (Corresponding Author) \\ Department of Education, Achva-College of Education, Israel \\ Tel: 972-522-290-045 E-mail: reingold@netvision.net.il \\ Hannah Abuhatzira \\ Achva-College of Education, Israel \\ Tel: 972-54-773-5517 E-mail: Channahmail3@gmail.com
}

$\begin{array}{lc}\text { Received: April 21, } 2011 & \text { Accepted: April 25, } 2011 \quad \text { Published: November 1, } 2011 \\ \text { doi:10.5539/ies.v4n4p160 } & \text { URL: http://dx.doi.org/10.5539/ies.v4n4p160 }\end{array}$

\begin{abstract}
The current paper analyzes a unique educational text that may be used to follow the educational policy of the State of Israel towards the community of Jewish immigrants from Ethiopia.

The text which was analyzed was a bi-lingual newspaper called Nugget News which is published under the sponsorship of the Israeli Ministry of Education, since 1999.

The analysis of the articles in the 59 issues of this newspaper was aimed to help us to reveal if there is a beginning of implementation of multicultural educational policy in Israel, or does the journalistic text express an explicit or implicit assimilation policy towards the immigrant community?
\end{abstract}

We discovered that the Nugget News newspaper acts according to the ideology of implicit assimilation of Ethiopian immigrant community by the State of Israel. Thus the newspaper is being used as an educational tool for promoting a fake multicultural policy.

Keywords: Multicultural Education, Assimilation, Bi-lingual Texts, Israeli Ministry of Education

\section{Introduction}

The paper deals with the bi-lingual newspaper called Nugget News published under sponsorship of 'The steering committee of Ethiopian immigrants' that is a branch of the Society for Advancement of Education of the Immigrant Absorption department in the Israeli Ministry of Education. The newspaper is distributed bi-monthly free of charge in secondary schools since 1999 in 22,000 copies. Two-thirds of the articles in the newspaper are in Hebrew (the official language of Israel), and one-third in Amharic (the original language of the immigrants). Nugget in Amharic means 'before dawn' and expresses hopes for the future. The newspaper deals with the way of life of immigrants inside the Israeli society, with emphasis on integration of immigrants in educational systems. Until now, 59 issues were published, and the current investigation has analyzed the articles of the newspaper quantitatively and qualitatively.

Publication of the newspaper in two languages, that is, also the immigrant minority language, apparently testifies to an adoption of multicultural policy. Since the newspaper is financed by the Ministry of Education and distributed by it, it becomes 'a behalf of' (Caspi and Elias, 2010), thus one may address it as an educating source and use it for analysis of ethical codes of the society, as it is done with textbooks. The educational system regards the textbooks as one of the most important instruments for communicating ideological messages. Accordingly, one may address the newspaper as a book (Helinger \& Brooks, 1991; Apple \& Christian-Smith, 1991). The newspaper as an educational tool is "intended to enrich the student by means of providing additional texts and constitutes a resource of various 
materials in the teaching process in a traditional class. In addition it constitutes 'an effective tool' for instilling knowledge (Hermann, 1981). Thus, the analysis in the present paper was designed to explore if the newspaper is meant to help the community in the process of integration into the Israeli society while strengthening the connection of its members to their cultural heritage, with openness towards the life in Israel and deepening the connection to the Israeli society? Does the newspaper constitute a means for preservation of the immigrant culture, while the language dimension is included in this culture (Walden, 2004)? Does it mean that the newspaper serves multicultural and pluralistic ideology? Or maybe this is an expression of a ethnocentric pluralistic approach?

One common assumption of most researchers that have studied the absorption of Ethiopian immigrants is the ideological assumption that the immigrants strive to integrate or even assimilate themselves in the mainstream of Israeli society. If it is the case, then the wish of Ethiopian immigrants corresponds to the policy of the absorbing country that has been applying to this group of new immigrants the policy of explicit assimilation along with implicit assimilation. The change of immigrants' names and their enforcement to enter certain educational frameworks is the carbon copy of the 'melting pot' or 'integration of Diasporas' policy enacted towards hundreds of thousands of Jews that have arrived to Israel from Islamic countries (the Mizrahiim) in 1950s. Partial recognition of folklore elements of Ethiopian immigrant culture is an expression of temporary pluralism or residual multiculturalism (Sever, 2001), which means ethnocentric pluralism which is a kind of implicit assimilation (Lamme, 1996).

Yet, many researchers have disregarded the main alternative attitude of Ethiopian immigrants -'everyday resistance'. The everyday resistance characterizes relatively powerless groups that use the weapon of misleading, make-believe, suspiciousness, creation of an alternative discourse and subversive use of language, songs, fables, humor, folk stories, etc. This attitude has characterized the Beta Israel people in their encounters with their Amharic and Tigrinya neighbors, and was developed also against the Israeli society as a reaction to what was perceived by the immigrants as an intrusive intervention in the community life. However, such an everyday resistance is usually perceived by the absorbing society as ignorance, as 'cultural shock', as objective difficulties, and as a product of intercultural gaps (Kaplan, 1997).

The current paper analyzes a social 'phenomenon' found between and inside the system of relationships between the absorbing policy and the absorbed community, the phenomenon that teaches or constitutes a testing criteria whether Ethiopian immigrants in Israel assimilate themselves and/or are assimilated, are rejected and segregated and/or put up everyday resistance, whether the policy of multiculturalism is applied towards them and they show, in response, attempts of integration into the Israeli society while preserving their unique culture and community pride.

\section{Theoretical Background}

\subsection{The Absorption of Beta Israel community}

The community of immigrants coming from Ethiopia numbering currently about 170,000 Israelis (CSB, 2008), suffers from racist attitude of considerable parts of Israeli population. The concise expression of the issue is given in the following sentence: “...When we came to Israel, we were sent to boarding schools in order to forget the culture we came from. The goal was a 'melting-pot' - to take people and integrate them into one culture..." (Nugget, September 2008, p. 6). This sentence emphasizes the processes of absorption of the social group by governmental bodies that was not characterized by an egalitarian and open attitude. The text analyzed in the current paper is based on the "subject matter" published by the entity subordinate to the Ministry of Education and called "The steering committee of Ethiopian immigrants' that is a branch of the Society for Advancement of Education of the Immigrant Absorption department in the Ministry of Education.

Against the backdrop of specific reactions of the Israeli society towards Ethiopian immigrants and the ongoing processes, the immigrants have started the process of attempting to integrate into the society, but the community of Ethiopian Jews still searches for 'correct' place for itself in the Israeli social contexture in the dimension of visibility or invisibility (Ben-Ezer, 2010).

On the one hand, the group strives to become visible and at the same time to become invisible. On the one hand, it is interested in becoming an integral part of the society into which they have arrived, in elimination of different treatment of its members that distinguishes them from other members of the group, that is, to become invisible, but, on the other hand, the members of the absorbed group strive to preserve their uniqueness, expect considerate attitude towards their specific characterization in unique aspects of their immigration. That, is the group strives to continue to preserve important aspects of its previous existence, from its socio-cultural past (Ben-Ezer, 2010).

The absorption of Ethiopian Jews (Beta Israel community) is characterized by numerous difficulties in various social 
systems in Israel in general and in the educational systems in particular. As a part of the attempt to treat properly the absorption of students of Ethiopian origin, the Ministry of Education has started to perform actions in order to find solutions for advancement of Ethiopian immigrants in educational systems.

It is important to analyze this phenomena is the context of the unique centralistic control system operated in the state of Israel by the Ministry of Education. The Ministry is actually responsible for determining the educational policy and inspection of implementation of pedagogical action. This control is noticeable at various educational levels: the Ministry is responsible for pre-academic studies, starting from the work of studies program development, which professional teams are subordinate to a department in the Ministry of Education. It approves the textbooks used in the routine school work. In addition, the Ministry controls the final exams testing the knowledge that the students have acquired during the course of their studies (Baratz \& Reingold. 2010).

\subsection{Between Ethnocentric Pluralism and Multicultural Pluralism}

In the first decades after the State of Israel was founded, the dominant social and educational policy was that of 'integration of Diasporas' or 'melting pot' (named after such policy in the United States). In the basis of such view of explicit assimilation there was the wish to move the Jewish immigrants from Islamic countries away from the cultures of their communities and integrate them in the framework of what was defined the Israeli culture, that is, the hegemonic and dominant one, the one that was a variation of the culture of the absorbing Ashkenazi elite (Sever, 2001). The goal of the melting pot policy was to hide the visibility of the immigrants; it caused formation of negative visibility that was a result of disregard of their culture and continuing discrimination (Resnik, 2010). This concept led to struggle against the melting pot conception and collective national identity and to advancement of multiculturalism that has created the need for foundation of a newspaper that would reflect the identity of the Ethiopian community.

The explicit assimilation approach is based upon the view that particular and inferior cultures of minority groups are to disappear, unlike the monistic view, that is, pluralism in which the point of view accepts the existence of various cultural groups in one political/social entity and even views it as normal (Lamme, 1996). However, "pluralistic splitting of societies does not constitute the ideal of proper world in the ideology of pluralism... but there still might be, within it, a place to strive... for cultural integration of different groups that may become realized precisely because of the recognition of their right to exist" (Ibid. p. 212). That is, a pluralistic ethnocentric version is actually a conception advocating implicit assimilation. Its goal is identical to that of explicit assimilation. Recognition of the right of ethnic groups and communities to preserve their separate cultures is a kind of inevitability, or even more than that - hypocrisy or even false recognition.

Israel advocates the principles of cultural pluralism that recognizes cultural differences between the immigrants and enables them to preserve it (Horowitz, 1999). Israeli society shows quite a large amount of openness towards ethnical and sectoral symbols and expressions, including the culture and the tradition brought by immigrants from C.I.S. (Shuval \& Leshem, 1998). Transition to cultural pluralism is reflected also in the change of status of the Hebrew language in the process of immigrant absorption. For forty years the State of Israel applied mono-linguistic policy in order to build a nation, since the Hebrew language and culture associated with it were considered a core of the Zionist revolution. The revolution has started in 1990s when the explanation bulletins were distributed also in Russian language (Alales, 2010).

Ethnocentric pluralism has two main variations: 'temporary pluralism' approach striving to adoption of the dominant culture by the whole society, but this process is to be gradual. On the other hand, 'residual multiculturalism' is an approach accepting permanent preservation of marginal cultural dimensions inside minority groups (Sever, 2001).

Still, pluralism may also serve as a basis for multicultural perceptions. The pluralist multicultural ideology does not require communities to renounce unique cultures of their own but strives to sustain a dialogue, at cultural boundary domains, between members of different cultural groups that preserve their particular cultures (out of recognition of these cultures and pride by them), without building cultural hierarchy or attempts of cultural colonialism (Reingold, 2005; Reingold, 2009). Educational expressions of this ideology may be construction of common educational public spaces which are common to members of different cultural communities, or, at an earlier stage, of different educational public spaces for members of cultural minority groups, in order to empower the community members and to prepare them for an intercultural dialogue from a position of strength, that is, to include an early stage of particular multiculturalism (Reingold, 2007).

\subsection{Affinity between Language and Identity - the Bilingualism Criterion}

Language is a tool for ideology evaluation, but it is also influenced by the ideological process. Language is not only a solution to the problems such as what is ideology and what does it do, but also a very important problem in the 
ideology (Cameron, 2006). In Israel, the attitude towards the original language of the immigrants is assimilation (Sever, 2007). Sever enumerates aspects of this assimilation process that include also the situation of trampling the mother tongue. In addition, she also sets forth arguments that in her opinion require preservation of immigrants' mother tongue.

Following Grant (1997), Sever surveys types of response of various societies with respect to lingual situation prevailing in these societies, while the language is one of the markers of identity for a threatened culture that tends to preserve its identity by means of the language. Grant indicates that from the point of view of language situation one may distinguish between: homogeneous society, small lingual minority concentrated geographically, dispread lingual minority, large lingual minority, and society with lingual division (Grant, 1997, from Sever, 2007). According to Grant's typological classification, Ethiopian community in Israel can be viewed as a dispread minority, a lingual minority that does not constitute a local majority in any geographical region in a given society, that is, the hegemonic Israeli one. Such minority tends to be especially vulnerable with respect to preservation of its language, since the spoken or written environment where it lives is that of the dominant language. Thus, their minority language lacks social support received in a language enclave.

In addition, Sever indicates the types of lingual policies, of which it is important for our case to mention the pluralistic policies, which recognize the minority languages for various purposes, including their use as a teaching tool. Preservation of the mother tongue of the immigrant student is a part of the commitment of the absorbing party adhering to the multicultural approach in the absorption processes. Teaching of reading and writing in the mother tongue has improved the image and the achievements of foreign-language talking people (Garcia \& Baker, 1995).

Is there a core of unique personal identity out of which one can choose or reject the cultural dictates, or, maybe, the identity is always a cultural construction? Do people formed by a certain culture have a capability to form their own personal identity? Or, maybe, to test it against the national identity that is a circumstantial and random product of various kinds of discourses and contexts where it is discussed? (Ben-Porat, 2007) Its perception is based upon the Gofman's theory of identity, suggesting that the identity is not a stable and fixed entity but is adjusted as a result of social interaction. The human being is a 'social actor' taking off and putting on the form inside a social situation defined by Gofman as a theatrical one. The conduction of the Ethiopian community inside the Israeli society is, therefore, a performative practice consolidated and disintegrated by means of interactions occurring within varying social situations (Ben-Porat, 2007).

Berry's theory of cultural suitability (Berry, 2003) sees in the social situation of immigration as a field of meeting between cultures: in this process one may talk about preservation of culture - this is the situation in which the people strive to preserve their identity and the processes of cultural adjustment or, alternatively, the situation of contact and co-operation in which people strive to come in touch with the whole society. In the process of cultural contact, according to Berry, four strategies of the cultural contact may be created: 1) integration - preservation of the original culture and acceptance of the foundations of the new culture; 2) segregation - voluntary preservation of the original culture and rejection of the new culture; 3) assimilation - renunciation of the original culture and acceptance of the new one; 4) marginality - renunciation of the original culture without acceptance of the new one. Following this approach, the process of absorption of Ethiopian immigrants was analyzed by Mane, Or and Mane $(2004,2007)$, and the researches have discussed mainly the process of adaptation of Ethiopian immigrants in the Israeli society and divided the integration process as follows: extended identity - that includes the concept of immigration as an enriching process from personal and group point of view that does not involve renunciation of the culture of the country of origin; competitive identity - considering the culture of the country of origin to be superior to the local one, and the demand to recognize it as a legitimate part of the existing context; separatist identity preservation of the original culture along with detachment from the local one. Acquiring the local language is considered to be one of the central components of the immigrants' new identity that is constructed as a result of the interaction between them and the host society. Survey of the bi-lingual newspaper texts illustrates the concept of 'political literacy' (Ichlov, 2001). According to the written text one can analyze the essence of the 'other', the extent of acceptance, and the degree of 'otherness'. The encounter with the text makes the reader meet himself and his own world.

Observation of visibility processes of immigrant groups requires attention to visibility' agents, but it is not enough: one has to analyze the tools and the mechanisms by means of which these agents 'view' the immigrants.

The bi-lingual literature has an important value in construction of the 'other"s identity (Zamir \& Baratz, 2010). Bi-lingual literature is a means for creating of the dialogue. Dialogue is one of the means for getting familiar with the other person with all his or her differences. The dialogue helps my 'self' to detect in himself or herself the human or unconscious part of himself or herself and thus to approach himself/herself (Ehrlich, 2001). The bi-lingual 
writing eliminates the concept of 'being different' since the typography derives from a location of equality. In the discussed situation, each reader turns at the same time into 'me' and 'other'. It depends upon his identity. That is, here is an ideology intended to propose the discourse of co-existence on the basis of egalitarianism and mutuality. Cultivation of ethnical identity enhances the feeling of belonging and commitment of a person towards a group and it contributes to the feeling of belonging to an organized social framework where the very fact of belonging to the group provides the feeling of connection contributing to positive self-concept. So, how does a bi-lingual text reflect the essence of identity?

\section{Methodology}

\subsection{The Research Aim}

The paper tries to describe the contribution of the bi-lingual Amharic-Hebrew press.

We shall discuss the question whether bi-lingual writing creates a kind of multicultural dialogue, that is, whether writing meant to be an organically built unit leads to pluralism or, maybe, to 'fake multiculturalism'?

\subsection{The Research Corpus}

This paper is based upon the analysis of the content of the Nugget News newspaper, published bi-monthly by the Ministry of Education. At the footer of the newspaper page it is written that the newspaper is "The newspaper of the steering committee of Ethiopian immigrants - Society for Advancement of Education". The head of staff of the newspaper is a former Beta Israel community member, while the editor is a native Israeli who does not belong to the Beta Israel community. (One has to mention the collaboration between the two writers.)

\subsection{Research Tools}

The research method is qualitative-interpretive; text analysis is to be performed according to the principle of critical discourse focusing upon the society problems and the various forms of misusing the language towards minority groups' underprivileged on the grounds of ethnical background or social status (Gee, 1992, 2004). In addition, the analysis was performed to expose explicit messages in the texts, both of political and of naïve symbolical nature (Klein, 2010).

Klein's method is aimed to analyze socio-cultural connections and implicit meanings resulting from them, following Van Dijk $(1988,1991)$. The analysis of the journalistic text should help to detect force and suppression foci that influence or form the identity of Ethiopian community members inside the hegemonic field of Hebrew-speaking Israeli community.

Barthes, (1974) method suggests 5 codes for text analyzing: the hermeneutic code, the semic code, the symbolic code, the proairetic code, the cultural code. We choose two codes: the semic code which defines motives that emphasizes vast verbal in the same subject. The symbolic code that represent contradict ideas that were found in the sub texts.

\section{Findings}

Hierarchic classification of themes has shown that the decisive majority of verbal contents concentrate in the field of education. The strengthening of encouragement for young people to leave the community for studies in higher-education institutions was detected. In addition, there are publications on scholarships for academic studies, family education, and articles and interviews on pedagogical events. From all the texts, the number of publications on education was 166 articles. The number of publications that have dealt with tradition and immigration stories was 40. The number of articles on racism was 19 , creativity -15 , health -15 , and employment -15 (See in details in appendix A).

In the light of the number of publications on education, we have asked to check newspaper contents on the subject and to analyze what words repeat themselves in these texts. The survey of the verbal content in these texts has resulted in finding various data that constituted in the following a pattern adjusted to the codes in the Barth's (1974) method that we have used as a basis

Aspects of learning processes were mentioned in 56 articles. The main subjects were: Encouragement of going to higher-education institutions; scholarships in the field of education; and pedagogical events in schools.

Personal success stories were the issue of 53 articles. The success stories of the community members dealt with various fields, mainly in education, politics and army service. (See in details in appendix B).

\section{Discussion}

The starting point of the discussion is that prima facie it seems that the bi-lingual newspaper represents the trend for multiculturalism, that is: dialogue from the position of equality. However, the analysis of findings shows that the 
newspaper Nugget News represents the trend of implicit assimilation of the Ethiopian immigrant community by the State of Israel by means of the educational system. The newspaper articles are mentioned that present unique elements of the community, such as: the voyage to the Land of Israel, the Sigd holiday, the community customs, etc. However, the number of such articles is relatively small, while most of the articles are devoted to the wish and to the tools for successful integration into the Israeli society.

Thus the articles in the newspaper constitute the indication of declaration of visibility, and ethno-cultural identity against the backdrop of Israeli society is emphasized in them. However, the main emphasis is made upon the desire of the ethnic group to integrate into the Israeli society, that is, a dimension of encouragement of assimilation exists (e. g., articles dealing with the success of a person, stories of community members).

An outstanding example of this process is the number of articles dealing with the stories of the voyage (24). By means of the voyage stories the community is striving to establish its identity after the voyage, so they are entered into the Israeli discourse by means of their re-writing, in order to obtain symbolic visibility through adopting the national narratives of suffering and the ethos of heroism (Ben Ezer, 2010).

Is this approach actually the one of multiculturalism or of fake multiculturalism? That is, did the State of Israel replace the threatening melting pot policy (explicit assimilation) by the policy that is not threatening but whose goals are the same, the policy of implicit assimilation? That is, does the new type of ethnocentric policy prevail under the disguise of multicultural policy? If the goal of the newspaper is to strengthen Ethiopian invisibility, then the content in fact indicates visibility. It presents the face of the community as a weak group. The analysis of the articles concerning the place of another interlocutor in the Israeli community, e. g. the Israeli native, is not there or is silenced. Thus the existence trying to be multicultural is eliminated.

The discourse presented in two languages creates 'a body of knowledge' about the culture of Beta Israel community, the culture that seeks to position itself within the Israeli society. Still, it is a living example of talks about the need for forming a society with real multicultural ethos in Israel, which are not accompanied by real multicultural ideology.

Our findings show that various texts include explicit call for reduction of messages intended to emphasize the success of the community members inside the whole society; these texts are written by the editorial board of the newspaper.

The rational is in the perception expressed verbally in the texts, according to which overemphasizing the successes of the community members emphasizes actually the state of inferiority. We have chosen to include this phenomenon inside the symbolic code, as a remarkable contrast to extensive documentation of the successes of community members in a variety of fields in many texts, a contrast of the kind of 'found vs. wished'. Such examples as "...the highest rank reached until now by an Ethiopian immigrant in IDF...", “...the first women managing the A broadcasting network... is a member of the community...", from many texts describing the successes of the community members constitute an exemplary contrast to the claim taken from one of the articles: "...since the 1980s until now, colorful headlines appear from time to time about the first Ethiopian that has done something that is apparently outstanding: 'The first Ethiopian officer... the first Ethiopian physician... Each community member holds the ridiculous title of 'the first Ethiopian'...", the double idea that is based, on the one hand, upon the emphasizing of success and on the other hand on an attempt to underrate it in order to reduce visibility.

Multiple use of the term 'community' within various text structures emphasizes the need to frame the social group again and again. The emphasis of the need for preservation of language and encouragement of exercising the language is intended to create separate identity for preserving the cultural component. The root 'ש. 2 ' (the Hebrew root of the word 'integrate') becomes the indicating code in the Barth's concepts. Instead of integrating communality, the writer prefers to use words like: integration, excellence, responsibility, and success, mainly to emphasize the human relationships inside the community, as opposed to the human relationships outside the community, that is, the Israeli society in general. In order to emphasize the disputes, one may identify the analogous structure of presentation of things as it happens in Israel (here) or, alternatively, as they were conducted in Ethiopia. The use of expressions shows a generalized view or metonymical view, the representative terminology indicates the direction of inclusion of the community as a social entity.

In addition, we have found texts in which there are calls to stop self- identification as a group and to integrate into the whole. The question is formulated as follows: “...So tell me, is there such a thing as the 'Ethiopian community'?" in the context of discussion dealing with elimination of distinguishing tagging and the need to integrate into the society (the idea repeated in various texts).

An additional contrast that was illustrated is expressed in the repeating comparison between social norms that 
existed in the past in Ethiopia and those existing in Israel. In many articles dealing with education, and mainly the formation mode of the family unit, competence of parents and teachers, and the issue of values, large differences are emphasized between Ethiopian past and Israeli present. The comparison is performed critically, in order to describe a real contrast between the successful educational norms that prevailed in the country of origin, and their deterioration in Israel.

"When a teacher in Ethiopia, whose authority washigh, called parents, they had arrived immediately... The educational system has removed responsibility from the parents... The parents have felt that here in Israel one does not expect anything from them..."

This citation is taken from one of the articles dealing with the issue of education, and it constitutes an example illustrating the contrast.

We have already mentioned that according to the functional-structural approach, the language is a means of forming a national identity, that is, in ethnocentric societies the language policy would be based upon lingual assimilation. Thus, bilingualism and bi-lingual literature may represent several approaches of the absorbing country (if it is the one that initiates the bi-lingual literature, or at least encourages it) and of the absorbed immigrants (if they are the initiators of the bi-lingual literature, or at least are its writers and/or readers). As for the country, it is possible that multicultural policy is meant but it is also possible that it is actually implicit assimilation and a kind of monocultural pluralism of the kind of temporary pluralism or residual multiculturalism. As for the immigrant community, voluntary integration may be meant along with the desire to keep certain cultural elements that may be an expression of the wish for assimilation, but not immediate and absolute, or a kind of particular multiculturalism.

There are immigrants who want to assimilate and trying to adopt the local language, while others strive to be different preserve the language as a means for preservation of original identity, according to the principle of building the identity formulated by Berry (2003). One may learn about the observation of this process also from the words of the editor-in-chief, Mrs. Batya Makover, as they were presented in the findings.

In the present research we have analyzed the characteristics of the bi-lingual newspaper Nugget News that is a kind of 'of and for the benefit of' medium (Caspi \& Elias, 2010) distributed in secondary schools and naturally also to the Ethiopian immigrant students, but it is important to emphasize that the newspaper is published by the Ministry of Education and in its name, and its editor-in-chief is not a community member. The analysis of such newspaper may teach about the absorbing policy and the point of view of the absorbed community.

\section{References}

Alalas, N. (2010). The use of media as a practice of visibility and invisibility: The "returning home" in Israel and in Germany, in: A. Lomsky-Feder and T. Rapoport (editors), Visibility at immigration - body, view, representation (pp. 161-191). Jerusalem: Van Lir Institute and Ha-Kibbutz ha-Meuhad (in Hebrew).

Apple, W. M., \& Christian-Smith, K. L. (1991). The Politics of the Textbook. N.Y: Routledge.

Barthes, R. (1974). S/Z An Essay (R. Miller, Trans). New York: Hill and Wang.

Baratz, L., \& Reingold, R. (2010). The Ideological Dilemma in Teaching Literature process-Moral Conflicts in a Democratic and Nationally Diverse Society: An Israeli Teacher Case Study. Current Issues in Education 13 (3). [Online] Available: http://cie.asu.edu/ojs/index.php/cieatasu/article/view/388

Ben-Ezer, G. (2007). The Voyage - the stories of the voyage of Ethiopian Jews 1977 - 1985, Beit-Shemesh: Modan Publishers (in Hebrew).

Ben-Ezer, G. (2010). Like a drop returning to the sea? Visibility and invisibility in the process of absorption of Ethiopian Jews, in: A. Lomsky-Feder and T. Rapoport (editors), Visibility at immigration - body, view, representation (pp. 305-328). Jerusalem: Van Lir Institute and Ha-Kibbutz ha-Meuhad (in Hebrew).

Ben-Porat, A. (2007). Death to the Arabs: the fear of the right-wing supporter, Megamot, 45(2), 218-245 (in Hebrew).

Berry, G. (2003). From melting pot to multiculturalism: Influences upon the high education system and preparation of social and educational workers, in: A. Leshem and D. Row-Stryer (editors), Cultural otherness as a challenge for human services (pp. 113-125). Jerusalem: Magnes, Hebrew University (in Hebrew).

Caspi, D., \& Elias, N. (2008). Two media systems: media of and for the benefit of minorities in Israel. Kesher, 37. 99-109 (in Hebrew).

Cameron, D. (2006). Ideology and language, Journal of Political Ideologies, 11 (2), 141-152. http://dx.doi.org/10.1080/13569310600687916 
Ehrlich, S. (2001). Otherness, boundaries, and dialogue - thoughts, in: H. Deutsch \& M. Ben-Sason (editors), The Other, between the human being, himself, and the Other (pp. 19-36). Tel-Aviv: Yedioth Aharonoth (in Hebrew).

Garcia, O. \& Baker, C. (1995). Policy and practice in bilingual education: A reader extending the foundations. Bristol, PA: Multilingual matters.

Helinger, D., \& Brooks, D. J. (1991). The Democratic Façade. N.Y.: Cole publishing Company.

Gee, J. P. (2004). Situated language and learning: A critique of traditional schooling. London: Routledge.

Gee, J. P. (1992). The social mind: Language, ideology, and social practice. Series in language and ideology. New York: Bergin \& Garvey.

Hermann, P. (1981). Newspapers are for children, Education instruction newspaper for parents [6] Edi-Torial brings great news for small people (Leisure activities with a children's newspaper), 23. (in Hebrew).

Ichlov, A. (2001), Education for being a citizen in the changing world: the trends in the world and in Israel, in: Y. Iram, S. Shkolnikov, Y. Cohen, and A. Schechter (editors), Values and education in the Israeli society (pp. 441-480). Jerusalem, the Ministry of Education (in Hebrew).

Klein, A. (2010). Analysis of critical discourse of newspapers, in: L. Kasan and M. Krumer-Nevo (editors), Qualitative investigation data analysis (pp. 230-254), Ben-Gurion University Publishers (in Hebrew).

Kaplan, S. (1997), Everyday resistance among Ethiopian Jews, view out of the research, view upon the research, Theory and criticism, 10, 162-173 (in Hebrew).

Lamme, Z. (1996). The idea of pluralism and its implementation in Israeli education, in: I. Gur-Zeev (editor), Education in the era of postmodernist discourse (pp. 207-220). Jerusalem: Magnes Publishers (in Hebrew).

Mane, A., Or, A., \& Mane, Y. (2004). The identity of adolescents from Ethiopia and Commonwealth of Independent States: organizational principles of unique cultural representation of immigrant absorption. Megamot, 43, 491-519 (in Hebrew).

Mane, A., Or, A., \& Mane, Y. (2007). Cultural representations, theories of social identity, and intercultural meeting: integrative model of social building of adolescents' identities. Megamot, 45 (1), 24-52 (in Hebrew).

Reingold, R. (2009). Multicultural ideology: terms, polemics, and educational meanings, Massad, 7, pp. 6-13 (in Hebrew).

Reingold, R. (2007). Promoting a True Pluralistic Dialogue- a Particularistic Multicultural Teacher Accreditation Program for Israeli Bedouins, International Journal of Multicultural Education, 9 (1), 1-14. [Online] Available: http://journals.sfu.ca/ijme/index.php/ijme/article/view/6

Reingold, R. (2005). Curricular models of multicultural pluralistic education - four event investigations from the USA Academy. Dapim, 40, 108-131 (in Hebrew).

Resnik, G. (2010). Visibility and identity in multicultural schools in Israel, in: A. Lomsky-Feder and T. Rapoport (editors), Visibility at immigration - body, view, representation (pp. 274-302). Jerusalem: Van Lir Institute and Ha-Kibbutz ha-Meuhad (in Hebrew).

Sever, R. (2001). Mix or interlace? The conceptual framework for analysis of issues of multiculturalism. Gadish 7. 45-54 (in Hebrew).

Sever, R. (2007). The absorption language: Immigrant absorption by means of active encouragement of preservation of the mother tongue and intercultural bridging in education, in: P. Peri (editor), Education in multicultural society (pp. 67-104). Tel-Aviv: Carmel Publishers (in Hebrew).

Van Dijk, T. A. (1991). Racism and the Press. London: Rutledge.

Van Dijk, T. A. (1988). News Analysis. Case studies of international and national news in the press. Hillsdale, NJ: Erlbaum,

Walden, Z. (2004). "Hebrew in Amharic? Amharic and Hebrew as a totality? - The proposal of a lingual policy in teaching Ethiopian immigrants", The echo of the new studio for teaching Hebrew language and culture, 87, pp. 3-17 (in Hebrew).

Zamir, S., \& Baratz, L. (2010). "Children's literature in Hebrew and Amharic as the means for building identity", The echo of the new studio for teaching Hebrew language and culture, 96, pp. 52-59 (in Hebrew). 
Appendix A

\begin{tabular}{|c|c|c|c|}
\hline $\begin{array}{l}\text { Super-cate } \\
\text { gory }\end{array}$ & Field & $\begin{array}{c}\text { No. of } \\
\text { mentioning }\end{array}$ & List of subjects \\
\hline \multirow[t]{6}{*}{ Education } & $\begin{array}{l}\text { Aspects of learning } \\
\text { processes }\end{array}$ & 56 & $\begin{array}{l}\text { Encouragement of going to higher-education } \\
\text { institutions, scholarships in the field of education, } \\
\text { pedagogical events in schools. }\end{array}$ \\
\hline & Personal success story & 53 & $\begin{array}{l}\text { Success stories of the community members in } \\
\text { various fields, mainly in education, politics, army. }\end{array}$ \\
\hline & $\begin{array}{l}\text { Projects in the } \\
\text { community }\end{array}$ & 29 & $\begin{array}{l}\text { Community seminars for youth and adults, } \\
\text { preparation for army, and classes. }\end{array}$ \\
\hline & $\begin{array}{l}\text { Parent-child } \\
\text { relationships }\end{array}$ & 24 & $\begin{array}{l}\text { Encouragement of parents' involvement in what is } \\
\text { going on with their children, parents' support of } \\
\text { educators in issues related to their children. }\end{array}$ \\
\hline & Attention Disorders & 4 & $\begin{array}{l}\text { Advices to parents about how to diagnose attention } \\
\text { and behavior disorders in their children, raising the } \\
\text { importance of the subject. }\end{array}$ \\
\hline & $\begin{array}{c}\text { Drugs and } \\
\text { delinquency among } \\
\text { youth }\end{array}$ & 3 & $\begin{array}{l}\text { Importance of parental supervision of youth } \\
\text { following mentioning of events of delinquency } \\
\text { among community youth. }\end{array}$ \\
\hline Actuality & News subjects & 18 & $\begin{array}{l}\text { Attitude of community members toward the issue } \\
\text { of 'Disengagement', attitude of soldiers originating } \\
\text { from the community to the issue of } \\
\text { 'Disengagement', 'Operation Cast Lead', } \\
\text { legislation issues. }\end{array}$ \\
\hline \multirow[t]{3}{*}{$\begin{array}{l}\text { Community } \\
\text { tradition }\end{array}$} & Racism & 19 & $\begin{array}{l}\text { Occurrence of violence as an act of racism, criminal } \\
\text { justice, racism at educational institutions }\end{array}$ \\
\hline & $\begin{array}{l}\text { Immigration and } \\
\text { nostalgia stories }\end{array}$ & 24 & $\begin{array}{l}\text { Stories on immigration events, reminiscences from } \\
\text { Ethiopia. }\end{array}$ \\
\hline & $\begin{array}{l}\text { Traditional Judaism, } \\
\text { Sigd }\end{array}$ & 16 & $\begin{array}{l}\text { Holidays and rites, The Sigd holiday and all its } \\
\text { aspects, all the discussions on the subject in the } \\
\text { State of Israel. }\end{array}$ \\
\hline \multirow[t]{3}{*}{$\begin{array}{l}\text { Everyday } \\
\text { issues }\end{array}$} & Employment & 15 & $\begin{array}{l}\text { Encouragement of going to work, providing } \\
\text { advices that would help in getting a job, data about } \\
\text { unemployment among community members. }\end{array}$ \\
\hline & Health & 15 & $\begin{array}{l}\text { Importance of vaccination, AIDS, correct nutrition, } \\
\text { denunciation of eating fats that is common among } \\
\text { the community members. }\end{array}$ \\
\hline & $\begin{array}{l}\text { Rights and juridical } \\
\text { consulting }\end{array}$ & 5 & $\begin{array}{l}\text { Consulting in the field of civil rights, according to } \\
\text { certain events that raise serious questions. Most of } \\
\text { the cases focus in the field of employment. }\end{array}$ \\
\hline \multirow[t]{3}{*}{ Cultural life } & Art & 15 & $\begin{array}{l}\text { Artists, writers, poets, actors, sculptors belonging to } \\
\text { the community, presentation of books dealing with } \\
\text { religiousfolklore. }\end{array}$ \\
\hline & $\begin{array}{l}\text { Successes in the field } \\
\text { of sport }\end{array}$ & 6 & $\begin{array}{l}\text { Youth groups succeeding in the field of sport, } \\
\text { distinguished sportsmen, mainly in the field of } \\
\text { athletics. }\end{array}$ \\
\hline & $\begin{array}{l}\text { Personality well } \\
\text { known in the } \\
\text { community }\end{array}$ & 4 & Death of personality well known in the community. \\
\hline
\end{tabular}




\section{Appendix B}

\begin{tabular}{|c|c|}
\hline $\begin{array}{l}\text { Denoting code (No. } \\
\text { of occurrences }\end{array}$ & Examples \\
\hline \multirow[t]{6}{*}{ Community (30) } & $\begin{array}{l}\text { "...So tell me, is there such a thing as the 'Ethiopian community'?" (Nugget } \\
\text { News, July } 2009 \text {, p. 13). }\end{array}$ \\
\hline & "...And the community members are powerless..." (Nugget, July 2007, title page) \\
\hline & “...To decide about the community's priorities...” (Nugget, February 2009, p. 2) \\
\hline & $\begin{array}{l}\text { "...We invite the young community members to write..." (Nugget, July 2009, p. } \\
\text { 2) }\end{array}$ \\
\hline & “...The community marches forward..." (Nugget, April 2010, p. 2) \\
\hline & $\begin{array}{l}\text { In the editorial article in the issue no. } 59 \text { (p. 2), Mrs. Batya Makover, the } \\
\text { editor-in-chief of the newspaper, writes the following about the community: } \\
\text { "Many articles in the newspaper are written by community members. We } \\
\text { welcome this phenomenon, and the goal is that more and more articles in the } \\
\text { paper are to be written by community members that would give expression to } \\
\text { their talents and opinions. The newspaper belongs to the community and not to } \\
\text { one editor or another." }\end{array}$ \\
\hline \multirow[t]{5}{*}{ Integration (10) } & $\begin{array}{l}\text { "The decision of the Ministry of Education to integrate the tradition of Ethiopian } \\
\text { Jews..." }\end{array}$ \\
\hline & "...Integration of the tradition of Ethiopian Jews in the education system..." \\
\hline & "...We have to integrate into various political frameworks..." \\
\hline & $\begin{array}{l}\text { "... One has to act for proper integration, striving for educational and social } \\
\text { involvement..." }\end{array}$ \\
\hline & $\begin{array}{l}\text { "...Higher education has an important influence upon our full integration into the } \\
\text { Israeli society..." }\end{array}$ \\
\hline \multirow[t]{4}{*}{$\begin{array}{l}\text { Improvement and } \\
\text { success (19) }\end{array}$} & $\begin{array}{l}\text { "...And this only emphasizes our commitment to help pupils belonging to the } \\
\text { community to succeed..." (Nugget, April } 2010, \text { p. } 3 \text { ) }\end{array}$ \\
\hline & “...Excellency instead of delinquency...” (Nugget, November 2009, p. 11) \\
\hline & $\begin{array}{l}\text { "...A woman soldier and a woman officer of the community have received an } \\
\text { award of excellence..." (Nugget, May 2007, p. 3) }\end{array}$ \\
\hline & $\begin{array}{l}\text { "... Success in studies and excellence at any place in order to prove to all how } \\
\text { mistaken they are..." (Nugget, September 2009, p.3) }\end{array}$ \\
\hline \multirow[t]{5}{*}{$\begin{array}{l}\text { Preservation } \quad \text { of } \\
\text { language (30) }\end{array}$} & $\begin{array}{l}\text { "...In the traditional Ethiopian family there were many customs of talk and } \\
\text { story-telling..." (Nugget, November 2008, p. 4) }\end{array}$ \\
\hline & $\begin{array}{l}\text { "...Parents that do not speak their native language with their children renounce } \\
\text { the possibility... to bequeath to their children the whole richness of the language } \\
\text { and the culture they have grown upon..." (Nugget, November 2008, p. 4) }\end{array}$ \\
\hline & $\begin{array}{l}\text { "...It is important to tell him stories and to talk... To tell the children about the } \\
\text { life in Ethiopia..." (Nugget, July 2008, p. 5) }\end{array}$ \\
\hline & $\begin{array}{l}\text { "...Children, talk Amharic and Tigrinya..." (Nugget, November 2008, p. 4); "He } \\
\text { has asked me to repeat after him word by word, letter after letter, I have done this. } \\
\text { I could read Amharic, but the Ge'ez words I didn't understand at all... Every } \\
\text { meeting included learning the language, the prayers, and the history..." (Nugget, } \\
\text { September 2008, p. 7). }\end{array}$ \\
\hline & $\begin{array}{l}\text { "... She speaks Amharic with her children, since it is very important to her that } \\
\text { they know the culture from which she has come..." (Nugget, November 2008, p. } \\
\text { 6) }\end{array}$ \\
\hline
\end{tabular}

